\title{
Kontekstualisasi dalam Penyebaran Islam: Analisis Pola Pembentukan Islam di Nusantara
}

\author{
Contextualization in the Spread of Islam: Analysis on the Pattern of \\ the Spreading of Islam in Nusantara
}

\author{
YANCE ZADRAK RUMAHURU 1
}

\begin{abstract}
This article analyzes the pattern of the spread of Islam in Nusantara, especially in Maluku islands. It aims to develop the thought of spread of Islam as proposed by Taufik Abdullah and Djoko Suryo. It is constructed based on the writer's research findings in Ternate and Tidore North Maluku, also in Ambon island and Haruku island, Central Maluku. Besides field data, literature study on the spread of Islam in Indonesia and Southeast Asia is used as well. Referring to the macro context proposed by Taufik Abdullah and Djoko Suryo, the writer examines the micro context of Maluku islands, and it is found that: First, the spread of Islam in Maluku takes place through a contextualization pattern. Second, the presence of Islam in Maluku islands is a momentum for the development of society in the past and influenced the existence of Islam until now. Through Islam, the local communities are able to realize the outside world and build a wider communication that allows them to experienced modernization. Furthermore, this article can be placed as part of the historical and religious identity studies undertaken to assert the existence of Islam that has contributed to build the civilization of society, either in Maluku or in Indonesia and Southeast Asia.
\end{abstract}

Keywords: contextualization, Indonesia, Islam in Southeast Asia, Maluku, Nusantara

Salah satu isu dalam kajian sejarah agama dan perubahan masyarakat di Indonesia mahupun pada negara lain di Asia Tenggara dengan penduduk majoritinya Muslim yang masih perlu dilakukan adalah terkait dengan model pembentukan Islam. Kajian tentang pembentukan Islam secara makro di wilayah Nusantara khususnya di Indonesia sekalipun telah dilakukan oleh banyak peneliti, tetapi hal tersebut masih menarik dianalisis kerana model pembentukan Islam pada setiap daerah berbeza antara atu dengan yang lainnya, dan disedari atau tidak model-model pembentukan Islam pada setiap daerah turut dipengaruhi oleh hubungan agama dalam masyarakat setempat, atau yang dikenal dengan istilah formasi sosial Islam. Dari berbagai kajian yang telah dilakukan tentang formasi sosial Islam, dapat disebut bahawa dalam konteks Indonesia hingga kini masih terus menjadi persoalan pelik terkait dengan isu tentang mode of transfer, mode of acceptance atau mode of translation yang diketahui memengaruhi perubahan sosial masyarakat secara budaya, agama, ekonomi dan politik (Surjo et.al 2001).

\footnotetext{
${ }^{1}$ Yance Zadrak Rumahuru, Ph.D., Director of Post Graduate Centre, Institut Agama Kristen Negeri Ambon (IAKN), Jln. Dolog Halong Atas, KOTA AMBON, Indonesia, email: rumahuru@yahoo.com.
} 
Cara agama (Islam) disampaikan kepada kelompok-kelompok masyarakat di wilayah Nusantara disedari atau tidak telah membentuk ciri tersendiri penerimaan kelompok-kelompok masyarakat lokal terhadap kewujudan agama tersebut. Bila dicermati penyiaran Islam di wilayah Nusantara seperti yang terjadi di Pulau Sumatra, Jawa, Nusa Tenggara, Sulawesi dan Maluku maka didapati model penerimaan Islam oleh masyarakat lokal setempat menunjuk pada hubungan agama dan masyarakat yang berbeza. Sudah tentu model penerimaan Islam yang berbeza tersebut mempengaruhi amalan keagamaan dan perkembangan masyarakat secara politik dan ekonomi, sehingga terdapat dinamika berbeza pula di antara kelompok masyarakat Islam di Nusantara.

Permasalahan utama penulisan ini adalah pembentukan Islam di Nusantara secara khusus di Kepulauan Maluku. Mengacu pada permasalahan sebagaimana disebut, maka terdapat dua pertanyaan yang dijadikan fokus pembahasan ini, masing-masing: (1) bagaimana model pembentukan Islam terjadi di Nusantara dan secara khusus di Kepulauan Maluku?, (2) Bagaimana formasi sosial Islam di Maluku ketika ini? Melalui kedua pertanyaan yang dijadikan fokus kajian ini, penulis akan menganalisis bentuk-bentuk pembentukan Islam terjadi secara makro pada wilayah Nusantara atau Indonesia, bagaimana pula pembentukan Isam terjadi di Kepulauan Maluku dan seperti apa formasi sosial Islam di Maluku, yang diharapkan dapat memberi penjelasan terhadap eksistensi Islam pada wilayah tersebut.

Disedari atau tidak, sejak awal pembentukannya, Islam telah meletakkan dasar penting bagi pembangunan masyarakat yang harmoni di Nusantara, bahkan di Asia Tenggara. Performa Islam di Nusantara yang menampakan wajah toleran dan damai, saat ini menghadapi tantangan sendiri. Salah satu tantangan saat ini adalah adanya fenomena radikalisme dan ekstrimisme agama, yang oleh sebagian kalangan dikaitkan dengan Islam. Padahal, eksistensi agama-agama secara khusus Islam mengajari pentingnya kerukunan dan kehidupan yang saling menghargai dalam keperbedaan.

\section{Analisis Literatur}

Dalam konteks Indonesia, penulis mengelompokan kajian antropologi dan sejarah tentang Islam dan masyarakat menjadi dua bahagian. Pertama, kajian tentang penyebaran Islam di wilayah Nusantara (Indonesia) dapat dilihat antara lain pada karya Ricklefs (2005), Reid (2004), Abdullah,T (1987). Dengan pendekatan sejarah, para penulis ini memiliki kesimpulan yang sama tentang penyabaran Islam yang dimulai dari daerah-daerah pesisir, yang merupakan jalur perdagangan ketika itu. Kedua, kajian tentang perilaku keagamaan komuniti Muslim, dapat dilihat pada kajian-kajian berikut: Geertz (1960; 1968), Hefner (1985), Beatty,A(1992), Ricklefs (2007), Nur Syam (2005), Budiawanti (2000), John Ryan Bartholomew (2001) dan Abdullah, Irwan (1994). Penelitian-penelitian ini membahas tentang Islam 1970dan komuniti lokal setempat dengan menggunakan pendekatan antropologi dan sejarah. Konteks kajian-kajian ini terutama pada masyarakat Jawa dan Nusa Tenggara Barat, dua tempat di mana terdapat pengaruh Islam yang kuat baik pada masa kerajaan Hindu dan Buddha abad ke 13 -15 M ataupun ketika ini. Dari pemetaan secara makro kajian Islam di Indonesia, kajian tentang Islam di Kepulauan Maluku masih termasuk minima, bahkan marginal dalam kajian utama Islam di Indonesia.

Kajian tentang sejarah dan pembentukan Islam di Kepulauan Maluku secara serius antara lain dilakukan oleh Putuhena 1997), Surjo(1993), Sahusilawane (1996), dan Rumahuru (2009;2012;2014). Berikut ini penjelasan tentang pendekatan dan temuan masing-masing.

1. Putuhena (1980; 1997), yang meneliti Islam di Ternate menemukan bahwa (1) telah terjadi perjumapaan masyarakat setempat dengan para pedagang Arab dan atau Persia pada abad sekitar abad II Hijriah atau pada abad VIII Masehi. (2) masuknya Islam ke Ternate (Maluku 
Utara) dibawah oleh empat orang Syehk dari Irak, masing-masing Syehk Mansur, Syehk Ya'cub, Syehk Amin dan Syehk Umar. Para Syekh ini meninggalkan Irak akibat pergolakan politik yang terjadi di negerinya. Keempat orang asing yang berfaham Syiah itu kemudian menyiarkan agama Islam di Ternate, Pulau Halmahera, Tidore dan Makian. Kedatangan keempat syehk ini dihubungkan dengan pergolakan politik yang terjadi di Irak, yakni peristiwa jatuhnya Bani Abbasyiah tahun 1258 Masehi atau pada pertengahan abad XIII.

2. Surjo et. al. (1993), meneliti hubungan antara Islam, masyarakat dan struktur sosial-politik di Indonesia, dan satu bagiannya membahas tentang Islam di Ternate. Penelitian ini menemukan bahwa pola relasi Islam dengan masyarakat lokal di Indonesia (Nusantara) terjadi sebagai berikut: (1) Melalui pembentukan pusat kekuasaan, model ini dicontohkan dengan Aceh. (2) Pribumisasi Islam, model ini dicontohkan dengan Ternate. (3) Negosiasi antara Islam dan adat, model ini dicontohkan dengan Minangkabau. (4) Penaklukan dan sinkritisme, model ini dicontohkan dengan kasus Lombok. Penelitian Suryo dkk memiliki posisi strategis dalam hal membicarakan formasi sosial Islam di Indonesia karena penelitian ini membuat pemetaan wilayah dari Barat ke Timur Indonesia dengan pilihan beberapa wilayah yang menjadi basis penyiaran dan perkembangan Islam saat ini, serta memberi analisis yang lebih komprehensif tentang pola pembentukan Islam dan perkembangannya sekarang.

3. Sahusilawane et.al. (1996: 8), melakukan penelitian di Jazira Leihitu, Pulau Ambon dengan pendekatan sejarah dan arkheologi. Penelitian ini menemukan bahwa agama Islam sudah melembaga di Maluku sejak awal abad 13 Masehi. Hal ini diperkuat dengan adanya bukti berupa dua buah naskah kuno yang ditemukan di rumah raja Hitu. Naskah pertama menjelaskan tentang kisah Nabi Muhammad, ditulis oleh raja Kulaba pada tahun 1234 dengan menggunakan bahasa Arab. Naskah kedua menjelaskan tentang hukum perkawinan dan hukum-hukum lainnya yang patut ditaati oleh masyarakat Hitu. Penulis naskah kedua ini tidak diketahui.

4. Rumahuru (2009; 2012), melakukan penelitian tentang Orang Muslim Hatuhaha di Pulau Haruku Maluku Tentah, dan tahun 2014 tentang formasi sosial Islam Maluku dengan konsentrasi Pulau Ambon (Maluku Tengah) serta Ternate dan Tidore (Maluku Utara). Penelitian-penelitian ini menggunakan pendekatan Sejarah dan Antropologi agama. Ditemui bahawa (1) Islam di Maluku merupakan kelompok Islam tua di wilayah Nusantara yang telah berkontribusi bagi pembentukan kultur dan pembangunan peradaban masyarakat sejak awal perjumpaan kelompok-kelompok masyarakat setempat dengan para pedaganag Islam terjadi abad VII dan VIII Masehi hingga pelembagaan Islam sebagai agama resmi masyarakat setempat pada abad XIII Masehi dan mengalami masa keemasan di abad XV dan XIV sebelum kedatangan bangsa-bangsa dari Eropa. (2) Kehadiran Islam memengaruhi tatanan ekonomi, budaya dan politik di kalangan masyarakat Maluku. Walau demikian terdapat perbedaan negosiasi Identitas islam di kalangan masyarakat di Maluku Tengah dan di Maluku Utara.

\section{Teori Tentang Masuknya Islam di Nusantara}

Kapan Islam masuk ke wilayah Nusantara, siapa yang membawahnya, dari mana asalnya dan bagaimana pula Islam disebarkan hingga kini masih menjadi perdebatan di kalangan pangkaji Islam. Kajian ini tidak memberi perhatian khusus terhadap hal tersebut, tetapi untuk memberi gambaran tentang masuknya Islam ke Nusantara maka dikemukakan konsep yang sudah mendapat 
kesepakatan di kalangan pangkaji Islam. Para ahli sejarah Islam berkesimpulan bahwa terdapat tiga teori tentang masuknya Islam ke Nusantara sebagai berikut: (1) Teori Gujarat, (2) Teori Makkah dan (3) Teori Persia. Ketiga teori tersebut mencoba memberikan jawaban terhadap permasalahan masuknya agama Islam ke Nusantara, dengan perbedaan pendapatnya: Pertama, terkait dengan waktu masuknya agama Islam. Kedua, terkait dengan asal negara yang menjadi perantara atau sumber tempat ajaran agama Islam. Ketiga, terkait dengan pelaku penyebar atau pembawa agama Islam ke Nusantara.

1. Teori Gujarat. Dinamakan teori Gujarat, bertolak dari asal negara yang membawa Islam ke Nusantara. Peletak dasar teori ini adalah G.W.J. Drewes dan dikembangkan oleh Snouck Hurgronje (Nur Syam 2005: 59). Pandangan Hurgronje didasarkan pada beberapa alasan sebagai berikut: (1) Kurangnya fakta yang menjelaskan peranan bangsa Arab dalam penyebaran agama Islam ke Nusantara. (2) Hubungan dagang Indonesia-India telah lama terjalin. (3) Inskripsi tertua tentang Islam yang terdapat di Sumatra memberikan gambaran hubungan antara Sumatra dengan Gujarat. Pandangan Snouck Hurgronje ini mempunyai pengaruh yang besar terhadap para sejarawan Barat, dan berpengaruh juga terhadap sejarawan Indonesia. Menurut teori Gujarat, Islam masuk ke Nusantara pada abad ke-13. Pendapat ini berdasarkan bukti batu nisan Sultan pertama dari Kerajaan Samudera Pasai, iaitu Sultan Malik Al-Saleh yang wafat pada 1297. Pendapat yang mengatakan bahwa nisan di Pasai tersebut becorak Hindu semakin menguatkan teori ini. Selain itu ajaran mistik Islam yang berkembang di Nusantara diakui dikembangkan oleh orang-orang India yang telah memeluk Islam.

2. Teori Makkah. Teori ini merupakan kritik terhadap teori Gujarat, yang dipelopori oleh Hamka. Beliau menolak pandangan yang menyatakan bahawa Islam masuk ke Nusantara pada abad ke-13 dan berasal dari Gujarat. Hamka lebih mendasarkan pandangannya pada peranan bangsa Arab sebagai pembawa agama Islam ke Nusantara. Gujarat dinyatakan sebagai tempat singgah semata, dan Makkah sebagai pusat, atau Mesir sebagai tempat pengambilan ajaran Islam. Selain itu, Hamka menolak pendapat yang menyatakan bahwa agama Islam baru masuk ke Nusantara pada abad ke-13, kerana di Nusantara pada abad ke13 telah berdiri kekuatan politik Islam,iaitu kerajaan Samudera Pasai. Menurutnya, tidak mungkin dalam waktu singkat setelah kedatangannya, umat Islam telah mampu membangun sebuah kekuatan politik. Jadi masuknya agama Islam ke Nusantara menurut Hamka tidak terjadi pada abad ke-13, melainkan jauh sebelum itu, iaitu pada abad ke-7.

3. Teori Persia. Teori Persia lebih menitikberatkan tinjauannya pada kebudayaan yang hidup di kalangan masyarakat Islam Indonesia yang dirasakan mempunyai persamaan dengan Persia. Kesamaan kebudayaan itu antara lain: (1) Peringatan 10 Muharram atau Asyura sebagai hari peringatan Syiah atas kematian Husain. Biasanya diperingati dengan membuat bubur Syura. Di Minangkabau bulan Muharram disebut juga bulan Hasan-Husain. (2) Adanya kesamaan ajaran antara ajaran Syaikh Siti Jenar dengan ajaran Sufi Iran al-Hallaj, sekalipun al-l-Hallaj telah meninggal pada $310 \mathrm{H} / 922 \mathrm{M}$, tetapi ajarannya berkembang terus dalam bentuk puisi, sehingga memungkinkan Syaikh Siti Jenar yang hidup pada abad ke-16 dapat mempelajarinya. (3) Penggunaan istilah bahasa Iran dalam sistem mengeja huruf Arab, untuk tanda-tanda bunyi harakat dalam pengajian al-Quran peringkat awal. 


\section{Metode Penyelidikan}

Tulisan ini dibangun dari penelitian penulis tahun 2012 dan 2014 dengan pendekatan kualitatif, baik studi lapangan mapun dokumen atau kepustakaan. Pada saat pengambilan data lapangan penulis berdasarkan pengamatan dan wawancara sebagai instrumen. Observasi dilakukan terhadap beberapa subjek yang menjadi rujukan Islam dan sejumlah ritual di kalangan masyarakat Muslim yang sedang dikaji. Melalui observasi penulis selain memferivikasi tempat-tempat yang menjadi rujukan dan destinasi Islam di Kepulauan Maluku, juga memahami secara langsung praktik keagamaan dan ritual-ritual di kalangan kelompok masyarakat Muslim Maluku. Wawancara dilakukan dengan sejumlah informan yang menjadi tokoh Islam pada wilayah masing-masing. Melalui wawancara, selain terdapat informasi baru terkait isu dan masalah yang dikaji, penulis juga mengkonfirmasi beberapa pendapat umum terkait pembentukan dan eksistensi Islam di Maluku. Selain data lapangan, penulis juga melakukan studi kepustakaan terhadap sumber-sumber dan kajian sebelum tentang Islam sebagaimana dikemukakan pada bagian analisis literatur.

\section{Model Pembentukan Islam di Nusantara}

Abdullah (1989) membedakan tiga pola penyebaran dan pembentukan Islam di berbagai daerah di Asia Tenggara. Pola pertama dirumuskan mengacu pada pengalaman Pasai sehingga ia disebut sebagai "Pola Pasai". Pola ini menunjukkan bahawa Islam tumbuh dan berkembang bersama-sama dengan perkembangan pusat kekuasaan negara, dan Islam menjadi landasan legitimasi negara. Pola kedua dirumuskan mengacu pada pengalaman Islam di Malaka, Patani, Gowa Talo dan Ternate, yang disebutnya sebagai "Pola Malaka." Menurutnya, dalam pola ini penyebaran dan penerimaan Islam (1) terjadi melalui kekuatan magis, (2) terjadi melalui konversi pusat kekuasaan lokal ke dalam kekuasaan Islam. Pola ketiga adalah "Pola Jawa" karena dirumuskan mengacu pada pengalaman penyebaran Islam di Jawa. Di dalam pola ini, penyebaran dan penerimaan Islam terjadi melalui penaklukan pusat kekuasaan lokal oleh kekuasaan Islam.

Mengacu pada kategori yang dilakukannya, Abdullah (1974) berkesimpulan bahawa penyebaran dan pembentukan Islam di Nusantara terjadi dalam dua pola atau bentuk. Pertama, pola integratif (integrative tradition) dan kedua, pola dialog (tradition of dialogue). Pola integratif merupakan gabungan dari kategori pola Pasai dan pola Malaka yang dalam pandangan Abdullah memungkinkan terjadinya pembentukan kultur Islam dalam masyarakat secara lebih baik kerana terjadi perubahan kekuasaan lokal kepada kekuasaan Islam. Dalam pandangan Abdullah, pola ini terjadi juga di Ternate, Maluku Utara. Pola dialog ditunjukan pada kategori pola Jawa dengan mengacu pada konteks pembentukan Islam di Demak. Menurut Abdullah, berbeza dengan pola integratif, dalam pola dialog terdapat pertentangan antara tradisi Islam yang berpusat di keraton dan tradisi keagamaan Islam di luar keraton yang membentuk model tersendiri tradisi Islam Jawa.

'Kritik terhadap teori Abdullah (1974), antara lain dilakukan oleh Surjo(1993) yang menawarkan empat pola relasi agama (Islam) dan masyarakat atau yang disebut dengan istilah formasi sosial Islam iaitu 'pola Islamisasi', 'pola pribumisasi', 'pola negosiasi' dan 'pola konflik'. Keempat pola yang dikemukakan ini merupakan telaah lebih jauh tentang dua pola penerimaan Islam di Indonesia yang dikemukakan oleh Abdullah(1974) iaitu, pola integratif (integrative tradition) dan pola dialog (tradition of dialogue). Menurut Suryo et.al., dalam konteks Maluku Utara, disebut bahawa pola relasi Islam dan masyarakat atau formasi sosial Islam di Ternate adalah pola pribumisasi (Surjo 1993: 218). 


\section{Model Pembentukan Islam di Maluku}

Dalam konteks Maluku, penulis menemukan bahawa pembentukan Islam di Kepulauan Maluku terjadi melalui kombinasi antara pola pribumisasi sebagaimana dikemukakan oleh Suryo dan pola dialog sebagaimana di sampaikan oleh Taufik Abdullah, yang dapat disebut sebagai pola kontekstualisasi. Penulis menyebut pembentukan Islam di Maluku terjadi melalui pola kontekstualisasi kerana: (1) terdapat dialektika antara agama Islam dengan adat komuniti lokal di Kepulauan Maluku. Dalam proses dialektika tradisi Islam dan adat atau tradisi komuniti lokal setempat dihasilkan satu perpaduan yang baik antara nilai-nilai Islam dengan nilai-nilai adat lokal yang dijadikan sebagai bentuk baru agama mereka. Hal ini terjadi baik di Maluku Tengah ataupun di Maluku Utara. (2) Pada saat konversi komuniti lokal yang beragama suku ke Islam, identiti lokal mereka tetap dipertahankan. Hal ini dapat difahami dengan melihat perpaduan ajaran agama dengan adat. Fenomena ini dapat dilihat pada komuniti Muslim Hatuhaha di Pulau Haruku. Bahkan, keagamaan kelompok Muslim di Maluku turut ditentukan juga oleh ketaatan terhadap adat. Di tempat lain konversi ke Islam cenderung meninggalkan bentuk-bentuk lama dari sistem kepercayaan dan bentuk keberagamaan mereka (secara nyata hal ini dapat dilihat pada komuniti Muslim Hatuhaha di Pulau Haruku). (3) Berkaitan dengan aspek pemerintahan, di Maluku Tengah komuniti lokal tetap menajalankan sistem pemerintahan saniri, yang umum digunakan oleh negeri-negeri di Maluku Tengah, dan tidak beralih ke sistem kesultanan yang lebih didominasi oleh sistem pemerintahan kebanyakan wilayah Muslim. Melalui sistem pemerintahan saniri, tidak ada hak-hak istimewa Islam di bidang ekonomi maupun politik, seperti yang terjadi pada daerah lain yang menganut sistem kesultanan, termasuk di Ternate, Maluku Utara.

Menurut hemat penulis, penyebaran Islam secara luas di Kepulauan Maluku terjadi dengan menggunakan cara dakwah, tetapi cara dakwah ketika itu berbeza dengan model dakwah yang sangat 'teologis' (dogmatik) sekarang ini. Berdasarkan berbagai cerita tentang kedatangan Islam dan konversi komunitas lokal menjadi Islam, penulis berkesimpulan bahawa penganut Islam awal di Maluku melakukan dakwah dan memperkenalkan Islam melalui cara hidup hari-hari yang baik di tengah komuniti lokal, hingga mereka benar-benar diterima oleh komuniti tempatan, barulah mereka memperkenalkan beberapa asas ajaran Islam bagi komuniti setempat. Model interaksi dan komunikasi Islam seperti ini oleh penulis disebut sebagai model 'dialog kehidupan' dan'“dakwa aksi'.

Melalui model 'dialog kehidupan' dan 'dakwah aksi', dalam waktu yang cepat para pedagang dan penduduk tempatan yang memeluk agama Islam berhasil menyibarkan agama Islam ke seluruh pelosok Kepulauan Maluku, sehingga pada saat orang Eropah tiba di Maluku, sebahgian besar negeri di Kepualuan Maluku, terutama di Ternate, Tidore, Pulau Ambon, Haruku, Saparua, Banda dan sebagian Seram yang ada di daerah pesisir telah memeluk agama Islam.

Perbincangan di atas dapat disimpulkan sebagai: pertama, pada level makro Indonesia atau Nusantara, pembentukan Islam terjadi dalam dua pola iaitu pola integratif (integrative tradition) dan pola dialog (tradition of dialogue). Kedua, pola ini dikembangkan oleh Surjo et.al. menjadi empat pola sebagai berikut: pola islamisasi, pola pribumisasi, pola negosiasi dan pola konflik. Ketiga, pada level mikro Maluku ditemui pembentukan Islam di Kepulauan Maluku terjadi melalui pola kontekstualisasi, merupakan perpaduan antara pola pribumisasi sebagaimana dikemukakan oleh Surjo dan pola dialog sebagaimana dikemukakan oleh Abdullah (1974). Keempat, kehadiran agama Islam di Nusantara, secara khusus Kepulauan Maluku merupakan momentum bagi perkembangan masyarakat beberapa abad silam dan memengaruhi eksistensi Islam hingga kini. Dikatakan demikian kerana melalui kehadiran Islam, masyarakat lokal setempat mengenal dunia luar dan membangun komunikasi lebih luas, yang memungkinkan mereka mengalami modernisasi. 


\section{References}

Abdullah, I. 1994. The Muslim Businessmen ofJatinom: Religious Reform And Economic Modernization In A Central Javanese Town. Amsterdam: Universiteit van Amsterdam.

Abdullah, T. 1974. Islam di Indonesia: Sepintas Lalu Tentang Beberapa Segi. Jakarta: Tinta Mas Indonesia.

Abdullah, T. 1987. Islam Dan Masyarakat: Pantulan Sejarah Indonesia. Jakarta: LP3ES.

Beatty, A. 1999. Varieties of Javanese Religion: An Anthropological Account. Cambridge: Cambridge University Press.

Budiawanti, E. 2000. Islam Sasak: Watu Telu versus Watu Lima. Yogyakarta: LKis.

Geertz, C. 1960. The religion of Java. Chicago: The University of Chicago Press.

Hefner, R.W. 1985. Hindu Javanese: Tengger Tradition and Islam. Princenton: Princenton University Press.

Nur Syam. 2005. Islam Pesisir: Yogyakarta: LKiS.

Putuhena, M.S. 2007. Historiografi Haji Indonesia. Yagyakarta: LKiS.

Putuhena, M.S. 2006. Interaksi Islam dan budaya di Maluku. In. Komaruddin Hidayat \& Ahmad Gaus AF (eds.), Menjadi Indonesia: 13 Abad Eksistensi Islam di Bumi Nusantara. Bandung: Mizan.

Putuhena, M.S. 1997. Proses perluasan agama Islam di Maluku Utara. Dlm. G.A. Ohorela (Pnyt.). Ternate Sebagai Bandar di Jalur Sutra: Kumpulan Makala Diskusi. Jakarta: Departemen Pendidikan dan Kebudayaan RI.

Reid, A. 2004. Sejarah Modern Awal Asia Tenggara. Jakarta: LP3ES.

Ricklefs, M.C. 2005. Sejarah Indonesia Modern 1200-2004. Jakarta: Serambi.

Ricklefs, M.C. 2007. Polarising Javanese Society: Islamic and Other Visions (c.1830-1930). Leiden: KITLV Press.

Rumahuru, Y.Z. 2012. Islam Syariah dan Islam Adat: Konstruksi Identitas Keagamaan dan Perubahan Sosial di Kalangan Komunitas Muslim Hatuhaha di Negeri Pelauw. Jakarta: Kementerian Agama RI.

Rumahuru, Y.Z. 2009, Islam "Pinggir": Konstruksi Identitas, Emansipasi dan Perubahan Sosial di Kalangan Komunitas Maluku Muslim di Pulau Haruku. Yogyakarta: LPPM UGM.

Rumahuru, Y.Z. 2014. Formasi Sosial Islam: Studi tentang Pembentukan Islam di Maluku, P3M, Sekolah Tinggi Agama Kristen Negeri Ambon.

Sahusilawane, F., ed. 1996. Arkeologi Islam Maluku di Kecamatan Leihitu Kabupaten Maluku Tengah. Ambon: Balai Arkeologi Ambon.

Surjo, Dj., Nasikum, Lay, C., Falakh, F., Zaman, B.K., Mundayat, A.A. \& Adelheida.1993. Laporan Penelitian. Agama dan Perubahan Sosia : Studi Tentang Hubungan antara Islam, Masyarakat, dan Struktur Sosial-Politik Indonesia. PAU-UGM.

Surjo, Dj., Nasikum, Lay, C., Falakh, F., Zaman, B.K., \& Mundayat, A.A. 2001. Agama dan Perubahan Sosial: Studi Tentang Hubungan antara Islam, Masyarakat, dan Struktur Sosial-Politik Indonesia. Yogyakarta: LKPSM dan Pusat Studi Sosial dan Asia Tenggara UGM. 